\title{
Mütoloogilist põhjavene külaelus tänapäeval ${ }^{1}$
}

\author{
Tatjana Iljina, Andrei Toporkov
}

\begin{abstract}
Teesid: Marc Blochi nimelise Venemaa-Prantsuse ajaloolise antropoloogia keskuse suveekspeditsioonidel (aastail 2003-2006) kogutud materjalidel põhinev artikkel püüab leida vastust küsimusele, kuivõrd aktuaalsed on tänapäeva Põhja-Venemaa külaelanike seas mütoloogilised kujutlused. Suurem osa narratiive on kogutud naistelt ja peegeldavad naiste spetsiifilist vaatenurka toimuvale. Vaatamata üldise kirjaoskuse juurutamisele ja massimeedia kättesaadavusele elavad paljud naised Põhja-Venemaa külades 21. sajandi alguses ikka veel justkui nõiutud maailmas, kus elavate ja surnute vahel pole selget piiri, metsas valitsevad loodusvaimud ja perekonflikte peetakse mõne vanema naissugulase kuritahtliku kaetamise tulemuseks. Laiemas laastus on artiklis juttu sellest, kuivõrd aktuaalsed on mütoloogilised arusaamad tänapäeva inimese silmis üldse.
\end{abstract}

Märksõnad: folkloor, külaühiskond, mütoloogia, Põhja-Venemaa

Käesolev artikkel põhineb Marc Blochi nimelise Venemaa-Prantsuse ajaloolise antropoloogia keskuse nelja suveekspeditsiooni käigus kogutud materjalidel aastatest 2003-2006. Aastatel 2003-2005 toimusid välitööd Karjala Vabariigi Pudoža rajoonis ja 2006. aastal Vologda oblasti Võtegra rajooni Andomski pogosti asualal, ${ }^{2}$ et koguda andmeid Põhja-Venemaa traditsioonilisest kultuurist ja ka praegusest sotsiaalsest olukorrast (vt lähemalt Toporkov 2006). Antud töös püüame vastata küsimustele, kuivõrd on mütoloogilised ettekujutused säilitanud oma aktuaalsuse Põhja-Venemaa külade elanike seas, millised folklooritekstid on säilinud nende repertuaaris ja kuidas neid tänapäeval modifitseeritakse. Laiemas laastus tuleb juttu sellest, kuivõrd aktuaalsed on mütoloogilised arusaamad tänapäeva inimese silmis üldse.

Mõistagi erineb praegune olukord oluliselt 19. sajandi teise poole ja 20. sajandi esimese kolmandiku rahvaluulekogujate kirjeldatust. See ala, kus me töötasime, oli varem tuntud bõliinade traditsiooni suurima koldena, kuid bõliinad on juba ammu minevikku vajunud. 
Külaühiskond on umbes 60 aastat veetnud sunniviisiliselt juurutatud ateismis, üle elanud kollektiviseerimise, Suure Isamaasõja, sõjajärgse laose, suurendamised ja Hruštšovi sula perioodi teised eksperimendid ning lõpuks nn perestroika ja sellele järgnenud kolhooside-sovhooside süsteemi krahhi. Meie külastatud külades kirikuid peaaegu ei ole, töötuse ja liigjoomise tase on kõrge, valitseb üldine sotsiaal-majanduslik stagnatsioon. Kuigi paljud külaelanikud peavad end õigeusklikuks, on nende teadmised kristlikust religioonist äärmiselt kasinad (Nikolajev 2006).

19. sajandil maagilise meditsiini ja uskumuste poolt reguleeritud sfäär on nüüdseks oluliselt kitsenenud. Haigestumisel pöördutakse arsti poole, kuid abiks võetakse ka rahvameditsiin ja vajadusel otsitakse üles posijast vanamemm. Naised sünnitavad nüüd sünnitusmajas, mitte kodus. Selle tulemusel on vähenenud sünnitusmaagia rakendamine ja möödanikuks saanud ämmaemanda amet. Pulmaprotseduurid on kahanenud miinimumini, aga viimastel aastatel eelistavad paljud noored naised hoopis üksikema staatust. Koos üldise majandusliku laostumisega kahanes järsult loomade arv. Sellepärast jäävad järjest rohkem minevikku ka karjaseamet ja sellega seotud usundid. Nõia kuju on juba ammu muutunud legendide ja muistendite osaks. Maagiaspetsialistid tegutsevad see-eest täiesti avalikult ja neid populariseeritakse ka massimeedias. Rahvatraditsioonide taaselustamisele aitab kaasa massikultuur. Posijad seletavad oma oskusi mõistega energia; külanaised saavad rahvameditsiinivahenditest teada ajalehest Aibolit. Etnograafidest saatejuhid räägivad televaatajatele maagilise ravimise ja teispoolsete jõududega suhtlemise kogemustest. Rahvademonoloogia kujundid modifitseeruvad tasapisi ja nt majavaim hakkab juba sarnanema poltergeisti või isegi Potsatajaga (Чебурашка).

Meie informantide seas on üpris palju kõrgharidusega inimesi: õpetajaid, raamatukoguhoidjaid, kultuuritöötajaid, külavõimu esindajaid. Mõned töötavad linnades ja maamaja kasutatakse suvilana. Meie vaadeldav kultuur on igas mõttes kaugel eraldatusest ja arhailisusest.

Väga sageli elavad meie informantide lapsed ja lapselapsed rajoonikeskustes Pudožas ja Võtegras või isegi sellistest suurlinnades nagu Petrozavodsk ja Vologda. Viibides suvel maal vanaema juures aitavad nad kaasa linna- ja külafolkloori segunemisele. Selle tulemusena kutsuvad lapsed [ennustamistel] ropendaja-eite ja Viktor Tsoid [vaimu]; õudusjutte mõjutavad arvudemängud (Solovjova 2006).

Nüüdisfolkloori näitena esitame kaks omapärase rahvaspiritismi ${ }^{3}$ kirjeldust. 
Sõja ajal metsaraiele saadetud noorukid kutsusid Puškini vaimu ahjukorstna kaudu. Jutustaja meenutab, et Puškini vaim vandus palju (EA 2006, Andomski pogosti Andoma küla, R. N. Troškova, s. 1931, kogunud A. A. Jefremova). ${ }^{4}$

Hiljuti kutsusid noorukid Andomski pogostis lahkunud rokklaulja Viktor Tsoi vaimu. Jutustaja memmeke palus neil küsida temalt oma eluiga. Noorukid ennustasid kaks korda ja mõlemal korral olevat laulja öelnud, et naine elab 85. eluaastani. Jutustaja ütleb selle kohta, et seda on liiga palju ja ta tahaks rutem ära surra (EA 2006, Andomski pogosti Marino küla, O. K. Nikitina, s. 1924, kogunud A. G. Aidakova \& A. L. Toporkov). ${ }^{5}$

Meie väisatud küladest on jäädvustatud palju narratiive suhtlemisest üleloomuliku maailmaga. Antud publikatsiooni piires saame vaadelda ainult jutte unenägudest ja teadvuse kaotamistest. Artikli suurema mahuga venekeelses variandis vaadeldakse ka jutte nõidusest pulmas ja kohtumistest metsavanaga.

\section{Suhtlemine surnutega unenägudes ja teadvuse kaotamisel}

Nii muistendites liikuvatest surnutest kui ka juttudes unenägudest on piir surnute ja elavate vahel äärmiselt habras. ${ }^{6}$ Unenägude tüüpilised süžeed seisnevad selles, et surnud ilmuvad elavatele ja kurdavad, et neile jäeti midagi kaasa andmata või on jäetud täitmata nende surmaeelsed soovid. Näiteks mattis ema poja oma kaelaristiga, sest ei leidnud poja oma üles. Hiljem leidis ta poja risti üles ja hakkas seda ise kandma. Selle peale ilmutas poeg end emale unes ja nõudis, et ema võtaks tema risti kaelast ära, ähvardades muidu ema kägistada (Andomski pogosti Marino küla).

Tavaliselt on unenäojutt mingit sündmust kirjeldava narratiivi loomuga. Üldjuhul toimub tegevus unenäos igapäevastes tingimustes: kodus või maja juures õues. Surnud ei erine väliselt elavatest, samas tegutsevad nad selle ja teise ilma vahel suhtlemise spetsiifiliste stsenaariumite piirides.

Enamasti tunnevad uurijad kõige rohkem huvi unenägude sümboolika ja nende seletamise süsteemi vastu. Unenägude seletamine põhineb tähenduslike sümbolite eristamisel unenägudest. Sama põhimõte on ka unenägude seletajate aluseks (Niebrzegowska 1994, Niebrzegowska 1996, Jakuškina 1999, 
Tolstoi 2003: 303-310). Kuid unenäo jutustamine ei seisne eri sümbolite ühendamises; me võisime korduvalt veenduda, et oma unenäo ümberjutustaja ei tunne selliseid sümboleid alati ära; unenäojutu tähenduslikkuse määravad vahel mitte nemad, vaid üldine situatsioon, tegelaste toimingud ja suhted.

Toome näiteks mõned tunnuslikud kirjeldused.

1. Posija V. A. Kuroptevale meenub, et ükskord nägi ta unes oma surnud isa ja too kutsus ta enda juurde elama. Isa teatas, et käib teises ilmas tööl ja koju tagasi tulles pole kedagi talle süüa teha. Kuid naine keeldus ja rääkis siis unes nähtust emale. Ema arvas, et peab peied korraldama. Mõne aja pärast ilmutas isa taas ennast Valentina Aleksandrovnale unes. Seekord palus ta tütrel küpsetada talle kakke [võisaia sort]. Tütar küpsetaski, nad mälestasid teda kodus, ja isa ei ilmunud enam (EA 2004, Pudoža rajooni Terebovskaja küla, V. A. Kuropteva, s 1928, kogunud T. S. Iljina \& A. L. Toporkov).

2. Pudoža rajooni Semjonovo küla naiselanik on rääkinud kogujatele, kuidas ta kujutab ette põrgut ja paradiisi. Tema sõnul paikneb paradiis surnuaias. Kes on milleski süüdi, seda sinna ei lasta, sellised seisavad 40 päeva teatud samba juures. ${ }^{7}$ Aga paradiisi minejad hakkavad kohe oma hauda jõudes tööle nagu eluajalgi (EA 2003, Pudoža rajooni Semjonovo küla, A. V. Aleksejeva, s 1928, kogunud B. Davis \& A. Kudinov \& A. L. Toporkov).

3. G. V. Semenjuk on rääkinud, kuidas tema venna- või õetütar olevat näinud unes teist ilma. Ta olevat näinud, et ta on majas ja majas lendleb helesinine kera. Kera liigub pööningule ja tema järgneb sellele. Naine tahab minna pööningule, kuid surnud vanaema ei luba teda sinna, öeldes, et vara veel. Naine kurvastas, purskas nutma ja ärkas üles, pisarad silmis. Lõpetuseks märkis jutustaja, et teise ilma niisama lihtsalt ei lubata (EA 2005, Pudoža rajoona Karševo küla, G. V. Semenjuk, s 1958, kogunud I. A. Kaneva \& J. V. Publitšuk \& A. L. Toporkov).

4. A. I. Stojanova nägi unes oma ema, kes palus lubada tal natuke pikutada tema voodis, sest on jooksnud tööasjus ja kaotanud oma koha. Tütar ei lubanud ja käskis enam mitte tulla. Lõpus märgib jutustaja selge rahuloluga, et ema pole ennast talle enam ilmutanud.

A. I. Stojanova näeb tihti unes oma poega. Unenägudes nutab ta poeg ja kurdab, et pole veel ostnud teises ilmas emale korterit. Ükskord ilmutas ta end unes vend Viktorile ja kutsus ta enda juurde elama öeldes, 
et teises ilmas on väga hea ja koos on neil elu lõbusam. Üles ärgates läks Viktor kohe surnuaiale, et vennaga "kohtuda". A. I. Stojanova seletas unenägu asjaoluga, et Viktor polnud ammu kalmistul käinud ja vend hakanud temast puudust tundma (EA 2005, Pudoža rajooni Krasnoborski alev, A. I. Stojanova, s 1931, kogunud I. V. Zahharova \& N. A. Kuznetsova \& D. N. Šaikenova).

5. Ükskord nägi K. M. Ustinova unes, et tema juurde koju tuli ta surnud poeg. Poeg tuli otse kööki, kaenlas oli tal mapp rahaga. Noormees jättis emale lauale mõned viiekümnesed kupüürid Lenini pildiga. Kuid Klavdija Mihhailovna rõõmustas mitte raha, vaid poja tuleku üle ja palus pojal temaga jääda. Poeg vastas, et ei saa jääda, sest õues teda ootavad poisid. Tõepoolest seisid tee peal noormehed ja ootasid nähtavasti teda. Naine arvas, et need noormehed on maetud koos tema pojaga (EA 2005, Pudoža rajooni Krasnoborski alev, K. M. Ustinova, s 1928, kogunud I. V. Zahharova \& J. V. Publitšuk).

Vaatamata lühidusele ja näilikule lihtsusele on need elavate inimeste ja nende surnud sugulaste kohtumissituatsioone kirjeldavad tekstid üpris keerulise struktuuriga ja täis sisedramatismi. Analüüsime esimest. Selle sisu on järgmine: surnud isa ilmub tütrele unes ja teatab, et teises ilmas jätkab ta töölkäimist; õhtul koju tulles näeb ta, et keegi pole teinud talle süüa, ja kannatab sellepärast; ta kutsub tütre enda juurde elama, et tütar teeks talle süüa; tütar loobub.

Olmelise kollisiooni taga peituvad sügavad elamused. Mõlemad tegelased unenäos kannatavad: isa sellepärast et keegi ei tee talle pärast tööd süüa, tütar sellepärast, et on sunnitud eitavalt vastama isa lihtsale ja õiglasele palvele. Tegelikult on selle taga surnud isa järele igatseva tütre üksildus ja süütunne.

Samas on situatsioonil ka teine aspekt. Isa palve on näilikule süütusele vaatamata üsna kuritahtliku loomuga: ta ei kutsu tütart lihtsalt külla, vaid katsub veenda teda kolima varem teise ilma ehk õhutab enneaegsele surmale. Milline roll on surnul? Kes ta on - kas tütrega kohtumist ihkav üksildane isa või teda hukata sooviv kuri surnu? Jutt on niivõrd lakooniline, et on võimalik oletada nii ühte kui ka teist. ${ }^{8}$

Tuleb märkida, et enamasti on unenägijad naised, kes näevad unes surnud vanemaid, mehi või poegi. ${ }^{9}$ Selles väljendub vilets demograafiline olukord: üldiselt surevad mehed naistest palju varem (joovad end põhja, sooritavad enesetapu, hukkuvad avariides), sageli surevad pojad emadest varem. 
Eluajal lahendamata jäänud pereprobleemid jäävad sageli alles ka pärast surma. Ühes teates ilmub isa tungivalt ja agressiivselt tütrele unes, karjub ta peale, kirub teda selle pärast, et kodus on koristamata ja teda on maetud kaltsudes.

Erilist huvi pakuvad jutud teadvuse kaotamisest, s.o sellest, kuidas sonimisel, letargilise une või kliinilise surma seisundis satub inimene teise ilma. ${ }^{10}$ Ühest teadvusekaotamise kirjeldusest selgub, et hauataguses ilmas on elu samasugune kui maal: inimesed töötavad, käivad heinal. Samas on erinevalt reaalsest külaelust korteriprobleem paradiisis juba lahendatud:

L. I. Seleznjova meenutab, et kui tema eakas vanaema oli väga haige, arvasid kõik, et ta sureb. Kuid mõne aja pärast vanaema oli toibunud ja teatas, et olevat käinud paradiisis. Paradiisi kirjeldas naine järgmiselt: seal on üks suur maja, kuid igaühel on omaette toake. Kõik käivad tööl - heina tegemas, valged puhtad riided seljas. Kõik paradiisi asukad olevat väga rahulolevad, rõomsad ja heatahtlikud. Naine olevat tahtnud sinna jääda ja küsinud, kas leidub talle tuba. Selle peale oli hallipäine taadike vastanud, et ta ei tohi veel sinna tulla, kuna tema tuba pole veel valmis, et ta tuleb, kui tuba on valmis, kuid nüüd peab ta tagasi koju minema (EA 2005, Pudoža rajooni Krasnoborski alev, L. I. Seleznjova, s 1948, kogunud J. V. Publitšuk \& A. L. Toporkov \& K. A. Homjakova).

K. M. Ustinova rääkis kogujatele, kuidas oli ta unes ämma juures teises ilmas käinud. Klavdija Mihhailovna mälestuste järgi on teine ilm värava taga ja mõlemal pool väravat seisavad strasnikud vintpüsside ja budjonnovkatega. Naine läinud sisse ja sattunud haigla moodi ruumi, kõikjal akendel olnud lilled. Kõigilt vastutulijatelt pärinud ta meheema kohta. Klavdija Mihhailovna meenutab, et meheema oli maetud kabeli taha ja unes suunati ta nimelt sinna. Kabeli juures kohanud ta tüdrukut, kes heitnud talle ette, et K. M. Ustinova oli heina niitmisel lõiganud maha kabeli juures kasvanud kasekesed. Klavdija Mihhailovna olevat palunud vabandust ja küsinud taas meheema kohta. Neiu soovitanud küsida (hiljuti lahkunud) velsker Nikolai Mihhailovitšilt, kes oli just möödumas. Klavdija Mihhailovna mälestuste kohaselt näinud velsker välja samasugune nagu eluajal, ainult et nägu olnud justkui hallitusega kattunud. Jutustaja küsinud talt meheema kohta ja too osutanud talle kabeli taha. Unes astunud Klavdija Mihhailovna justkui haiglapalatisse, kus kõik olnud nagu haiglas ikka: meheema olnud voodis pikali, voodi kõrval olnud toiduga öökapp. Lähedal olnud Klavdija Mihhailovna õde, kes oli maetud hoopis teisele kalmistule. Kuigi teine ilm olnud tavalise haigla moodi, ei unustanud naine hetkekski, kus ta on: kui ämm ulatanud ter- 
vituseks käe, ei tahtnud ta oma kätt anda, sest uskumuste kohaselt ei anta surnutele kätt.

Teises jutus on K. M. Ustinova osa võtnud koosolekust teises ilmas. Asi olevat olnud nõnda. Ükskord oli naine palunud pojal kalmistule lilli viia, kuid päeval ei jõudnud too seda teha ja sõitis sinna õhtul. Kui poeg tuli tagasi, ema sõimas teda, sest hilisõhtul pole kombeks surnuaias käia. Ja öösel nägi Klavdija Mihhailovna unes, et ta on surnuaias, kuid haudade asemel on üks suur maja. Ta läinud sisse, seal olnud koosolek. Esimesena võtnus sõna naisterahvas ja öelnud: "Vaat, seltsimehed, mis ma tahan öelda: hilja meile siia tullakse.” Klavdija Mihhailovna saanud kohe aru, et jutt on temast. Hirmus hakanud ta kohe andeks paluma ja lubanud edaspidi hilisel ajal surnuaeda mitte minna. Koosoleku lõppedes tulnud ta välja, kergendusega löönud risti ette ja tänanud Jumalat lunastuse eest (EA 2005, Pudoža rajooni Krasnoborski alev, K. M. Ustinova, s 1928, kogunud I. V. Zahharova \& J. V. Publitšuk).

Meie kirjapanekutele nii iseloomulike ettekujutusi sellest, et surnud käivad teises ilmas tööl, leidub ka varasemates unenägude ja teadvuse kaotamiste üleskirjutustes, nt:

Üks suri ära. Eidekese järgi tuli, oma naise järgi. "Meil pole valvurit, tule minuga."

Naine vastab: "Mis valvur minust, mul on nii käed kui jalad kõhnad."

"Midagi, uksel istud, valvad.” Nemad käivad tööl, nii peab korteriuksel valvama (Tšerepanova 1996: 30, nr 43, kogutud Novgorodi oblastis 1988. aastal). ${ }^{11}$

1990. aastal rääkis üks naine Novgorodi oblasti Pestovo rajooni Rukatõ külas, kuidas suri tema mees: kalmistult tulid tema juurde surnud ja kutsusid metsa langetama; mees oli valmis kohe minema, kuid surnud ütlesid, et polnud veel käsku; kui tuleb käsk, tulevad nad tema järgi. Mõne päeva pärast nad tulid; mees pani riidesse, võttis varupintsaku, mängukaardid, isegi lõhnaõli ja odekolonni, hakkas õnnest nutma ja suri ära (Tšerepanova 1996: 29 nr 42).

\section{Järeldused}

Vaatamata üldise kirjaoskuse juurutamisele ja massimeediale elavad paljud naised Põhja-Venemaa külades 21. sajandi alguses ikka veel justkui nõiutud maailmas, kus elavate ja surnute vahel pole selget piiri, metsas valitsevad loodusvaimud ja perekonflikte peetakse mõne vanema naissugulase kuritahtliku kaetamise tulemuseks. 
Vaadeldav situatsioon on üsna vastuoluline. Ühest küljest jätkub kauges minevikus uskumuste ja maagia poolt reguleeritud eluala ahenemine, nagu see on toimunud terve 20. sajandi vältel. Sotsiaalsest ja maailmavaatesfäärist väljatõrjutud mütoloogilisus jääb pidama enamjaolt perekonnasiseses ja individuaalses sfääris, seletades perekonflikte, tagades suhtlemise elavate inimeste ja nende surnud vanemate vahel, reguleerides inimese käitumist ekstreemsetes olukordades metsas. Teisest küljest on sellised sfäärid nagu rahvalik õigeusk ja maagiline meditsiin elanud 1990. aastate algusest üle teatud renessansi, siirdunud pere seest ühiskondlikku sfääri, kus nad toituvad ka linnakultuuri mõjutustest. Arhailised rahvaluulevormid säilitavad vanu mudeleid, kuid lähenevad seejuures modernsusele ja imavad endasse nüüdisaegse elu uusi elemente.

Uute tegelaste seas, kes satuvad justkui juhuslikult ennustamiste, kutsumiste ja muistendite tekstidesse, võib kohata 19. sajandi poeeti (A. S. Puškin), 20. sajandi poliitikut (I. V. Stalin), hiljuti lahkunud rokklauljat (Viktor Tsoi). Surnud poeg toob emale V. I. Lenini portreega paberrahad.

Ühiskonnas, mis on sunniviisiliselt jäetud ilma religioossete teadmisteta elust pärast surma, suureneb unenägude tähtsus. Selles olukorras on unenäod ja teadvuse kaotamised ainus kättesaadav ja enim usaldatav tunnistus hauatagusest ilmast. Kuid nende nägemuste sisu transformeerub oluliselt ühiskonnas, kus on lõhutud kirikuid, hävitatud või ära viidud ikoone ja aastakümnete vältel levitatud riiklikku ateismi. Kuigi inimesed näevad jätkuvalt surnuid unes ja külastavad minestamisel või koomaseisundis hauatagust ilma, ei leia see müstikakogemus kujunemiseks enam tuge kristlikest sümbolitest.

Tänapäevaste unenägude ja teadvuse kaotamiste toopika on peaaegu täiesti ilma religioosse loomuta. Teises ilmas pole paradiisi ega põrgut, surnud elavad lihtsalt edasi surnuaias. Surnud sugulased ei ole patused või vagad inimesed, nad ei ole õnnejoovastuses ega tunne piina, nad lihtsalt töötavad edasi, nagu tegid seda eluajal. Kui nad ikkagi kannatavad, siis mitte põrgupiinade pärast, vaid igatsusest ja üksildusest. Ülivalgete palatite või tulejõe asemel võtavad unenägijat vastu haigla- või baraki-taolised hooned. Teejuhiks teises ilmas on velsker või medõde, mitte peaingel Miikael või püha Nikolaus. Põhiline teadmine, mida K. M. Ustinova saab teisest ilmast, ei kuulu müstilisse või eetilisse sfääri, vaid olmelis-rituaalsesse valdkonda: hilja õhtul ei tohi kalmistule minna. Teises ilmas kohtab naine inimesi budjonnovkate ja vintpüssidega.

Astudes üle elu ja surma vahelise piiri käivad inimesed edasi tööl, kuid teises ilmas saavad nad elamispinna ilma igasuguste probleemideta. Need asjaolud teevad surnute olukorra soodsamaks kui elavate oma külas, kus ena- 
mik meestest on töötud ja täiskasvanud pojad on sunnitud elama koos vanematega.

Unenägusid jutustatakse alati nii, nagu oleksid nende tegelased ikka inimesed, mitte nende kehatud kujud. Surnud kutsuvad oma sugulastes esile segast hirmu, süüd ja haletsust. Need tunded koos harjumusega suhelda rituaalselt surnutega (peietel, 40 päeva jooksul pärast matust, haual käimisel) määravad unenägude süžeesid paljuski juba ette.

Raske on öelda, mil määral on see rahvatraditsioon vastavuses unenägude ja teadvuse kaotamiste kirjeldustega teistes kultuurikihtides: käsikirjalistes ja trükitud unenägude seletajates, teise ilma nägemuste originaalsetes ja tõlgitud juttudes, ilukirjanduses, filmikunstis ja nüüd veel tõlgitud raamatuteski, mis käsitlevad elu pärast surma. Vaatamata individuaalsele karakterile on unenäod siiski osa sümboolsest ja narratiivitraditsioonist, millel on sügava arhailisuse jooned. On võimalik, et mitte üheski teises tänapäevase suulise külaproosa žanris pole esindatud selle algkuju nii silmnähtavalt kui juttudes teadvuse kaotamistest ja unenägudest, aga eriti suhtlemisest surnud sugulastega.

Põhja-Venemaal on tänini levinud olmelise põhjaga ebausujutud, mida jutustatakse memoraatidena ehk tunnistustena sündmustest, mis leidsid reaalselt aset ja juhtusid jutustaja enda või tema sugulaste ja tuttavatega. Nendeks on muuhulgas süžeed ühtede pereliikmete kaetamistest teiste pereliikmete või nõidade poolt pulmas, kohtumistest metsavanaga, vanadest karjastest, kellel oli karjase vabastus ja kes sõlmisid metsavanaga lepingu, et too aitab neil karja hoida; kohalike elavate või surnud posijate initsieeritud imetervenemistest.

Jutustavates tekstides kohtumistest üleloomulikuga esineb ilmse või spontaanse kunstlikkuse jooni. Nad on üles ehitatud teatud žanrikaanonite järgi ja on vahel väga huvitavad. Nende esitamisega kaasnevad elav miimika, rikkalik intonatsioon, vahel ka naer või muu emotsioon. Selle repertuaari valdamine rikastab külaelaniku emotsionaalset ja intellektuaalset maailma.

See, et neid tekste esitatakse kui jutte reaalselt toimunud sündmustest, lisab neile erilise võlu, kusjuures kogujatel on raske kindlaks teha, kas informandid tõepoolest usuvad seda, mida jutustavad, või ainult müstifitseerivad sündmusi. Tagamaks normaalset suhtlemist informandiga peab koguja jutustavat samuti uskuma või vähemalt teesklema uskumist.

On hämmastav, kui kergelt hakkavad kohalikud elanikud juba 15-minutilise suhtluse järel kogujatele rääkima, kuidas on surnud vanemad neile unes ilmunud või kuidas nad ise on suhelnud metsavanade ja majavaimudega. Mälestused kohtumistest üleloomulikuga on selline isiklik omand, millest juhuse 
korral räägitakse meeleldi sugulaste ja lähedaste või teiste vestluskaaslastega, ka etnograafilistest ja rahvaluuleekspeditsioonidest osavõtjatega.

Kokkuvõtteks märgime, et valdav enamik narratiive on kogutud naistelt ja peegeldavad spetsiifilist naiste vaatenurka toimuvale. Juttudes perekaetamisest on naine kannataja, kes ei tunne ennast vastutavana halva olukorra eest. Tekst kujutab endast omamoodi eneseõigustust, selle eesmärgiks on seletada kujunenud olukorda kui kaetamise või ettemääratuse resultaati ja mitte kui eksliku valiku või omaenese mõtlematuse tulemust (Golovanova, ilmumas).

Vaatamata nüüdisaegsetele modifikatsioonidele on meie kogutud tekstid üsna arhailise loomuga. Asjaolu, et nad funktsioneerivad edasi elavas repertuaaris, annab tunnistust rahvakultuuri heast säilimisest uuritud külades. Ja siiski säilitavad sellised nähtused nagu suhtlemine surnud sugulastega või kaetamine pulmas oma aktuaalsuse mitte ainult sotsiokultuurilistel, vaid ka individuaalpsühholoogilistel põhjustel. Võib öelda, et personaalne mütoloogia toitub üksildusest ja ebaõnnest elus.

\section{Tõlkinud Nikolay Kuznetsov}

\section{Kommentaarid}

1 Töö on valminud Venemaa humanitaarsegrandi 08-04-003180 "Suuline jutustamine biograafia ja muutuva maailmapildi uurimise allikana" raames.

${ }^{2}$ Materjal koguti järgmistes asulates: Karjala Vabariigi Pudoža rajooni külades: Avdejevo, Bostilovo, Burakovo, Jartževo, Kanzanavolok, Karševo, Kuganavolok, Nigižma, Podporožje, Samino, Semjonovo, Terebovskaja ja Krasnoborski alevis (20032005); Vologda oblasti Võtegra rajooni Andomski pogosti külades: Andoma, Gonevo, Derevjagino, Knjazevo, Kürzino, Marino, Mitrovo, Mihaljovo, Novaja Derevnja, Rebovo, Trošigino (2006). M. Blochi nimelise Venemaa-prantsuse ajaloolise antropoloogia keskuse etnoloogilise arhiivi (Moskva, Venemaa riiklik humanitaarülikool) materjalidele viidatakse artiklis koos vastava teksti kogumisaasta ja -kohaga.

${ }^{3}$ Rahvaspiritismist ja eraldi A. S. Puškini kutsumistest vt Zaporožets 1999, Adonjeva 2001: 68-69, Zaporožets 2002: 104-105, Pantšenko 2006.

${ }^{4}$ A. S. Puškini käitumine vastab täiesti tema mainele huumoris:

Anekdoodis on Puškin huligaan, skandaalitseja, ta tegutseb piiri peal, eirates sageli viisakuskombeid ja läheneb sel moel folkloorsele "sõdurile" (Morozov \& Frolova 1999: 22).

5 Viktor Tsoi [vaimu] kutsumistest vt ka Solovjova 2006: 61.

6 Viimaste aastate publikatsioonid näitavad, et suhtlemine surnutega on Venemaa maapiirkondades jätkuvalt aktuaalne (Jasinskaja 1998, Dobrovolskaja 2006).

7 Vanavene tekstidest hauataguse ilma kohta on teada nn mõlemapoolsetest või ükskõiksetest, kelle hulka kuuluvad ka eluajal nii patuseid kui ka häid tegusid sooritanud surnud; sellised patused võivad teises ilmas olla seotud samba külge 
paradiisi ja põrgu vahel (Pigin 2006: 196-197). See pole ainuke näide sellest, et unenäo detail võib pärineda vanast jutustavast traditsioonist.

${ }^{8}$ Et unenäod loovad surnu ambivalentse kuju, pani hiljuti tähele J. V. Safronov (2006a: 126); vt ka Safronov 2006b: 29 ja tema artiklid aadressil http://www.ruthenia.ru/ folklore.

9 Mitmes I. A. Razumova töös on näidatud, et jutud endelistest unenägudest mängivad tähtsat rolli tänapäeval individuaalse ja peresisese mütoloogia kujunemisel (Razumova 2001: 106-123, Razumova 2002, Razumova 2003).

10 Selle žanri ajaloost Venemaal vt Pigin 2006. Autori arvates on nägemuste žanri toopika ühtne kogu selle ajaloo vältel: 19.-20. sajandi ilmutusenägija näeb sisuliselt samu kujusid kui tema kauge eelkäijagi (Pigin 2006: 20). Meie materjalid lubavad selles kahelda. Igal juhul erinevad 20. sajandi lõpu ja 21. sajandi alguse teadvusekaotused oluliselt žanri varastest näidetest. Omaette uurimuse teemaks võiks olla see, kuidas on toimunud nägemuste vanavene toopika transformatsioon ja paralleelselt tunginud neisse kaasaegse elu elemendid. Faith Wigzell märgib, et nägemuste sisu oleneb nii sotsiaalsest kontekstist kui ka ilmutusenägijate soolisest kuuluvusest; 19. ja 20. sajandile on iseloomulik nägemuste siire klerikaalsest keskkonnast sekulaarsesse ja meessfäärist naissfääri; see tõi kaasa nägemuste funktsioonide ja moraalsete aktsentide muutuse (Wigzell 2006: 294).

${ }^{11}$ Vt ka Lurje \& Tarabukina 1994: 26. Nagu märgib J. V. Safronov, tegelevad surnud "teises ilmas" samaga, millega eluski, nt autojuht, kasvataja, pottsepp on ka pärast surma oma ametit pidamas (Safronov 2006a: 121). Samuti esitab ta unenägija ja surnu iseloomuliku vestluse: "Baba Sar, kuidas sa seal elad?" - "Hästi elame, töötame, meil on hea...” (Kogutud Uljanovski oblasti Karsuni rajooni Potma alevis M. S. Mitinalt, s 1932) (samas).

\section{Allikad}

ЕА = Этнологический архив Российско-французского центра исторической антропологии им. М. Блока. Российский государственный гуманитарный университет, Москва [Venemaa riikliku humanitaarülikooli Marc Blochi nimelise Venemaa-Prantsuse ajaloolise antropoloogia keskuse etnoloogiline arhiiv].

\section{Kirjandus}

Adonjeva 2001 = Адоньева, Светлана Б. Категория ненастоящего времени (антропологические очерки). Санкт-Петербург: Петербургское востоковедение.

Golovanova (ilmumas) $=$ Голованова Анна. Представления жителей Андомского погоста о порче на свадьбе.

Dobrovolskaja 2006 = Добровольская, Варвара. «Умереть сегодня -страшно, а когданибудь - ничего...». Знаки, предвестия и предчувствия смерти в традиционной культуре Центральной России. ЖКвая старина 2, lk 30-33. 
Jakuškina 1999 = Якушкина, Елена. Народный сонник из Каргополья. Живая старина 2, lk 29-30.

Jasinskaja 1998 = Ясинская, Мария. Поверья о покойниках в Уржумском районе. Живая старина 3 , lk 47-48.

Lurje \& Tarabukina 1994 = Лурье, Михаил Л. \& Тарабукина, Арина В. Странствия души по тому свету в русских обмираниях. Живая старина $2,1 \mathrm{k} \mathrm{22-26.}$

Morozov \& Frolova 1999 = Морозов, Игорь \& Фролова, Ольга. Е. Пушкин в анекдоте. Живая старина 4, lk 21-23.

Niebrzegowska 1994 = Небжеговска, Станислава. Сонник как жанр польского фольклора. Славяноведение 5, lk 67-74.

Niebrzegowska, Stanisława 1996. Polski sennik ludowy. Lublin: Wydawnictwo Uniwersytetu Marii Curie \-Skłodowskiej.

Nikolajev 2006 = Николаев, Дмитрий. Из наблюдений над религиозной ситуацией в Пудожском районе. Полевые исследования студентов РГГУ: Этнология. Фольклористика. Лингвистика 1. Москва, lk 53-57.

Pantšenko 2006 = Панченко, Александр. Русский спиритизм: культурная практика и литературная репрезентация. Богданов, Константин \& Мурашов, Юрий \& Николози, Риккардо (koost ja toim) 2006. Русская литература и медицина: Тело, предписания, социальная практика. Москва: Новое издательство, lk 123-147.

Pigin 2006 = Пигин, Александр. Видения потустороннего мира в русской рукописной книжности. Санкт-Петербург: Дмитрий Буланин.

Razumova 2001 = Разумова, Ирина. Потаенное знание современной русской семьи: Быт. Фольклор. История. Москва: Индрик.

Razumova 2002 = Разумова, Ирина. Ониромантическая символика брака, рождения, семрти в современных устных рассказах. Неклюдов, Сергей \& Христофорова, Ольга (koost). Сны и видения в народной культуре: Мифологический, религиозно-мистический и культурно-психологический аспекты. Москва: Российский государственный гуманитарный университет, lk 290-309.

Razumova 2003 = Разумова, Ирина. Мифологические рассказы о вещих снах в контексте семейного опыта. Путилов, Борис. Фольклор и народная культура. In memoriam. Санкт-Петербург: Петербургское Востоковедение, lk 382-393.

Safronov 2006à = Сафронов, Е. В. “Иной мир” в рассказах о сновидениях и комплексе представлений, связанных с похоронно-поминальными обрядами русских. Сны и видения в славянской и еврейской культурной традиции. Москва: Сэфер, Институт славяноведения РАН, lk 115-130.

Safronov 2006b = Сафронов, Е. В. Умершие как персонажи современных рассказов о снах. ЖКивая старина 2, lk 29-30.

Solovjova 2006 = Соловьева, А. А. Детские “вызывания" в Пудожском районе. Полевые исследования студентов РГГУ: Этнология. Фольклористика. Лингвистика 1. Москва, lk 57-63. 
Zaporožets 1999 = Запорожец, В. В. «Александр Сергеевич Пушкин, выйди к нам...». Живая старина 4, lk 23.

Zaporožets 2002 = Запорожец, В. В. Сны и видения как часть ясновидения (По материалам, собранным в москве летом 1998 г.). Неклюдов, Сергей \& Христофорова, Ольга (koost ja toim). Сны и видения в народной культуре: Мифологический, религиозномистический и культурно-психологический аспекты. Москва: Российский государственный гуманитарный университет, $1 \mathrm{k}$ 95-115.

Tolstoi 2003 = Толстой, Никита. Очерки славянского язычества. Москва: Индрик. Toporkov 2006 = Топорков, Андрей. Пудожские экспедиции Российско-французского центра исторической антропологии им. М. Блока. Полевые исследования студентов РГГУ: Этнология. Фольклористика. Лингвистика 1. Москва, lk 42-45.

Tšerepanova 1996 = Черепанова, Ольга (koost ja kommentaarid). Мифологические рассказы и легенды Русского Севера. Санкт-Петербург: Издательство С.-Петербургского университета.

Wigzell, Faith 2006 = Вигзелл, Ф. Моральный аспект обмираний и его связь с гендером и обществом. Кормина, Жанна \& Панченко, Александр \& Штырков, Сергей (toim). Сны Богородицы: Исследования по антропологии религии. СанктПетербург: Эвропейский Университет, lk 290-302.

\section{Summary}

\section{Mythology in the Contemporary Life of North-Russian Villages}

Tatyana Ilyina \& Andrey Toporkov

Key words: folklore, mythology, North Russia, village community

The article, which is based on materials collected in the course of the four summer expeditions of the Marc Bloch Russian-French Centre for Historical Anthropology (RSUH) in 2003-2006, attempts to answer the question to which degree have mythological conceptions preserved their topicality among the population of North-Russian villages; which folklore texts have been actively preserved in their repertoire; and how these texts have been adapted in modern life.

Relying on informant narratives, the authors agree that irrespective of the introduction of general literacy and mass media and even at the onset of the 21st century, many women in these North-Russian villages still live as if in an enchanted world where there is no clear boundary between the living and the dead, where the forests are the realm of spirits of nature, and family conflicts are believed to result from the casting of 'evil eye' by some elderly female relative. The majority of the narratives have 
been collected from women and specifically reflect women's perspective to the situation.

While the main focus of the article is dream narratives, the authors also discuss the topicality of mythological beliefs for the modern people. In the community which has been deprived of religious understanding of what will happen after death, dreams play a rather important role because they are the only available and the most trustworthy evidence of the world beyond the grave. The content of these beliefs, however, is bound to transform in a society where churches have been demolished, icons have been destroyed or removed, and atheism has been officially endorsed for dozens of years. Despite contemporary adaptations, the texts collected by the authors are rather archaic in nature. The fact that they are still part of active repertoire points to the viability of folk culture in the villages under investigation. And still, rituals such as communicating with the deceased relatives or casting an 'evil eye' at weddings continue to be practised not because of sociological or cultural reasons but also of personal psychology. It could be agreed that individual mythology feeds on isolation and misfortune in life. 